\title{
HORNER'S SYNDROME DURING EPIDURAL ANAESTHESIA FOR ELECTIVE CAESAREAN SECTION
}

\author{
Michael N. Skaredoff and Sanjay Datta
}

\begin{abstract}
Twenty $\mathrm{ml}$ of three per cent chloroprocaine solution was injected into the lumbar epidural space of a parturient for anaesthesia for elective caesarean section. Ten minutes after injection of the anaesthetic, the patient developed Horner's syndrome on the left side. The anaesthetic level was $\mathrm{C} 7$ on the affected side. Thirty minutes after the bolus dose of chloroprocaine the signs disappeared, at which time the patient received a reinforcing dose of $10 \mathrm{ml}$ of chloroprocaine three per cent. The Horner's complex reappeared in eight minutes and persisted for 20 minutes.

While Horner's syndrome is not uncommon in women in labour receiving lumbar epidural anaesthesia, it is virtually unknown in patients who are not in labour. The mechanism for the appearance of the syndrome in this case is unclear. The most likely explanation is that only a small amount of local anaesthetic was necessary to produce the syndrome and the subsequent bolus of anaesthetic followed pathways opened by the original dose, since a much smaller amount of anaesthetic was necessary to reproduce the syndrome.
\end{abstract}

\section{Key Words: Anaesthetic Techniques, epidural: Obstetrical Anaesthesia, complications, Horner's syndrome.}

THE occurrence of Horner's Syndrome (miosis, ptosis, enopthalmos and anhidrosis) has been noted occasionally during epidural anaesthesia. It has been most frequently reported after thoracic epidural analgesia in patients with chest injuries $^{1.2}$ and after high doses of local anaesthetic during lumbar epidural anaesthesia for parturients in labour. ${ }^{3,4}$ This report concerns itself with the appearance and reappearance of Horner's syndrome during lumbar epidural anaesthesia with a short-acting local anaesthetic, chloroprocaine, for elective caesarean section.

\section{RePORT OF A CASE}

A thirty-year-old woman was admitted to the Boston Hospital for Women for repeat caesarean section. She was $175 \mathrm{~cm}$ tall and weighed $78.2 \mathrm{~kg}$. She had undergone a previous caesarean section the year before under epidural anaesthesia with bupivicaine, without complications. Epidural anaesthesia was again elected.

Following the placement of an intravenous

Michael N. Skaredoff, M.D., ${ }^{*}$ Fellow in Obstetric Anaesthesia; Sanjay Datta, M.D., Assistant Professor of Anaesthesia, Harvard Medical School; Boston Hos pital for Women, 221 Longwood Avenue, Boston, Massachusetts 02115, USA.

*Present address: Dept. of Anesthesiology, University Hospital, State University of N.Y. at Stony Brook, Stony Brook, N.Y. 11794. catheter and the infusion of $1200 \mathrm{ml}$ of lactated Ringer's solution, with the patient in the left lateral position, an epidural catheter was easily inserted at the L2-3 interspace and directed $2 \mathrm{~cm}$ cephalad. After a test dose of $3 \mathrm{ml}$ of chloroprocaine 3 per cent the patient was turned supine with a $30^{\circ}$ head-up tilt and the uterus was displaced to the left by a blanket roll under the right hip and torso. Twenty $\mathrm{ml}$ of chloroprocaine three per cent was then injected through the catheter. Blood pressure remained unchanged at $120 / 75 \mathrm{mmHg}$. About ten minutes after the injection of local anaesthetic the patient developed miosis, ptosis and congestion of the conjunctiva of the left eye. The left side of the face felt drier than the right side. Anaesthetic levels to pinprick were noted to be $\mathrm{T} 3$ on the right side and $\mathrm{C} 7$ on the left. The operation was begun. Anaesthesia was excellent and a $\mathbf{4} \mathrm{kg}$ male infant was delivered with Apgar scores of $8 / 9$. Thirty minutes after the bolus dose of anaesthetic all signs of Horner's syndrome had disappeared. Ten minutes later, a reinforcing dose of $10 \mathrm{ml}$ of chloroprocaine three per cent was given. Within eight minutes of Horner's complex reappeared and persisted for twenty minutes. Anaesthetic levels to pinprick were T3 on the right side and T2 on the left. The procedure was completed without further incident and the patient recovered uneventfully. 


\section{Discussion}

The first clinical description of Horner's syndrome was given by Hare ${ }^{s}$ in 1839 . He described enopthalmos and injection of the corneal vessels in a patient with a tumour compressing the cervical sympathetic ganglia. Claude Bernard ${ }^{6}$ and others $^{7-9}$ in the 1850's confirmed François du Petit's observations of $1727,{ }^{10}$ describing ipsilateral vasodilation, pupillary constriction and retraction of the eye in its socket when the cervical sympathetic ganglia in animals were sectioned. Horner, ${ }^{11}$ in 1868 , gave the complete description of the syndrome which bears his name.

The cardinal signs are miosis, ptosis and enopthalmos. ${ }^{12}$ Enophthalmos in man is more apparent than real. ${ }^{13}$ Finally, there is vasodilation and anhidrosis on the ipsilateral side of the face.

Two other signs can also be appreciated. The first concerns visual accommodation. Sympathetic stimulation flattens the lens and accommodates the eye for distance while parasympathetic stimulation allows the eye to focus on nearby objects. ${ }^{14,15}$ While sympathetic paralysis does not usually make a subject grossly myopic, the feature is detectable on optometric examination.

The other component is a lack of pigment deposition in the iris. ${ }^{16}$ However, cervical sympathetic blockade must be present since birth for this feature to be apparent.

Current anatomical knowledge holds that preganglionic fibres originate from the anterior horn cells of $\mathrm{C} 8$ and $\mathrm{T} 1 ;{ }^{17}$ on occasion they may originate from as low as T4. ${ }^{18}$ These fibres course through the rami communicates to the cervical sympathetic chain. The fibres ascend through the stellate and middle cervical ganglia to terminate in the superior cervical ganglion. Unmyelinated fibres leave this ganglion to form the internal carotid plexus. The internal carotid plexus later divides to give rise to the cavernous plexus. ${ }^{19}$

Fibres from the internal carotid plexus innervate the smooth musculature of the orbit, the musculus dilator pupillae, the involuntary muscle of the upper eyelid (m. tarsicus) and the muscle of Müller which helps maintain the normal position of the eye. ${ }^{20}$ Other fibres course from this plexus through the three divisions of the trigeminal nerve and end either in vasoconstrictor or sweat gland musculature of the face, head or neck.

From the cavernous plexus, most fibres enter the orbit through the superior orbital fissure and send branches to the rectus superior and the levator palpabrae superioris. Some fibres pass through the sympathetic root of the ciliary ganglion and short ciliary nerves. ${ }^{21}$ Others reach the eye to innervate the dilator pupillae through the long ciliary nerves, bypassing the ciliary ganglion. 22

Stimulation of these pathways causes mydriasis, retraction of the upper lid and exopthalmos. In contrast, blockade results in unimpeded parasympathetic stimulation reaching the eye by way of the ciliary ganglion causing miosis, ptosis and, in animals, enopthalmos. Interruption of the sympathetic chain below $\mathrm{Tl}$ may cause incomplete oculopupillary changes. ${ }^{23}$

Horner's syndrome has been described in women receiving lumbar epidural anaesthesia during labour. ${ }^{3.4}$ However, after reviewing the literature no report could be found describing the appearance of Horner's syndrome during lumbar epidural anaesthesia in a non-labouring full-term parturient. The apppearance of Horner's syndrome during epidural anaesthesia is in itself not uncommon. In 1972 Kepes and coworkers ${ }^{24}$ first reported a case of Horner's syndrome following caudal epidural anaesthesia in an obstetrical patient in labour following the administration of $22 \mathrm{ml}$ of chloroprocaine three per cent. However, the duration of the clinical signs was not reported. Mohan and Potter ${ }^{25}$ in 1975 noted pupillary changes in 17 of 20 parturients who received either lidocaine or bupivicaine for caudal anaesthesia in labour.

The interest in this case lies in the fact that the initial signs of Horner's syndrome appeared within ten minutes of the injection of only $20 \mathrm{ml}$ of local anaesthetic. Furthermore, the full complex reappeared promptly after injection of only $10 \mathrm{ml}$ of local anaesthetic. Burn ${ }^{26}$ has shown that large $(40 \mathrm{ml})$ volumes of radio-opaque media consistently reach thoracic and cervical levels in nonpregnant patients whereas $20 \mathrm{ml}$ volumes fail to do so. Bromage ${ }^{27}$ has suggested that during intense labour small amounts of local anaesthetic may be driven cephalad. During the second stage of labor, initiation of the Valsalva maneuver when the patient "bears down" compresses the epidural space and may also force small amounts of local anaesthetic cephalad. It is also well known that, in order to achieve equal levels of anaesthesia, parturients need only one-third to one-half as much anaesthetic as non-pregnant patients. ${ }^{28}$ In our case the patient did not receive an excessive volume nor was she in active labour. 
Although the precise mechanism is not clear, a plausible explanation may be that the cervical sympathetic nerve fibres are very sensitive to anaesthetic blockade, as probably only a small amount of the original dose reached the $C 7$ level. The fact that the signs reappeared after a second dose one-half the volume of the first may be accounted for by invoking Bromage's concept of epidural spread following "in the wake of the pathfinding dose", 27 in which the tissue planes are spread by the initial volume and a smaller volume later might able to spread over a large area.

This report suggests that even when appropriate volumes of local anaesthetic are used during lumbar epidural anaesthesia for elective caesarean section one might encounter an unexpectedly high anaesthetic level. Further doses of anaesthetic may follow a path opened by the first dose.

\section{REFERENCES}

I. Mohan, J., Lloyd, J.W. \& Potter, J.M. Pupillary constriction following extradural analgesia. Injury 5: 151 (1973).

2. Mclean, A.P.H., Mulligan, G.W., Otton, P. \& MACLEAN, L.D. Hemodynamic alterations associated with epidural anesthesia. Surgery 62: 79 (1967).

3. Evans, J.M., Gauci, C.A. \& Watkins, G. Horner's syndrome as a complication of lumbar epidural block. Anaesthesia 30: 774 (1975).

4. Carrie, L.E.S. \& Mohan, J. Horner's syndrome following obstetric extradural block. Br. J. Anaesth. (correspondence) 48:611 (1976).

5. HARE, E.S. Tumor involving certain nerves. Lon. med. Gaz. 23: 16 (1839).

6. BERnARD, C. Influence du grand sympathetique sur la sensibilité et sur la calorfication. C. R. Soc. Biol. (Paris) 3: 163 (185I).

7. Budge \& Waller. Recherches sur le systéme nerveux. I. Action de la partie cervicale du nerf grand sympathetique et d'une portion de la moelle épiniere sur la dilitation de la pupille. C.R. Acad. Sci. (Paris) 3: 370 (1851).

8. Bernard, C. Sur les effets de la section de la portion céphelique du grand sympathetique. S.R. Soc. Biol. (Paris) 4: 168 (1852).

9. Brown-SÉquard, C.E. Experimental researches applied to physiology and pathology. Med. Exam. (Philadelphia) pp. 481-504 (1852).
10. Du Perrr, F. Sur ce que le nerf intercostal fournit des Esprits aux Yeux. Histoire de L'académie royal des Sciences (Paris) pp. 7-10 (1727).

11. Horner, J.F. Ueber eine Form von Ptosis. Klin Mbl. Augenheilk. 7: 193 (1869).

12. Monro, P.A.G. Sympathectomy. London: Oxford University Press (1959).

13. Pochin, E.E. Ocular effects of sympathetic stimulation in man. Clin. Sci. 4: 79 (1939).

14. Morgan, M.W. The nervous control of accomodation. Am. J. Optom. 21: 87 (1944).

15. Melton, C.E., Purnell, E.W.\& Bracher, G.A. The effect of sympathetic nerve impulses on the ciliary muscle. Am. J. Opthal. 40 (No. 5. pt. 2): 155 (1955).

16. White, J.C., Smithwick, R.H. \& Simeone, E.A. The Autonomic Nervous System, 3rd ed. New York: Macmillan (1952).

17. Brock, S. \& Krieger, H.P. The Basis of Clinical Nurology, 4th ed. Baltimore: Williams and Wilkins (1963).

18. Ray, B.S., Hinsey, J.C. \& Geohegan, W.A. Observations on the distribution of the sympathetic nerves to the pupil and upper extremity as determined by stimulation of the anterior roots in man. Ann. Surg. 118: 647 (1943).

19. Pick, J. The Autonomic Nervous System. Philadelphia: Lippincott (1971).

20. Clara, M. Das Nervensystem des Menschen, 3rd ed. Leipzig: Johan Ambrosius Barth Verlag (1959).

21. Alpern, M. Accomodation. In Davson, H. (ed.), The Eye, Vol. 3, 2nd ed. New York: Academic Press (1969).

22. Goss, C.M. (ed.) Gray's Anatomy, 28th ed. Philadelphia: Lea and Febiger (1970).

23. Hyndman, D.R. \& Walkin, J. Sweat mechanism in man; study of distribution of sweat fibers form sympathetic ganglia, spinal roots, spinal cord and common carotid artery. Arch. Neurol. Psychiat. 45: 446 (1941).

24. Kepes, E.R., Martinez, L.R., Pantuck, E. \& STARK, D.C.C. Horner's syndrome following caudal anesthesia. N.Y. State J. Med. 72: 946 (1972).

25. Mohan, J. \& Potter, J.M. Pupillary constriction and ptosis following caudal epidural. Anaesthesia 30: 769 (1975).

26. Burn, J.M., Guyer, P.B. \& Langdon, L. The spread of solutions injected into the epidural space. Br. J. Anaesth. 45: 338 (1973).

27. Bromage, P.R. Epidural Analgesia. Philadelphia: W.B. Saunders (1978).

28. Bromage, P.R. Spread of analgesic solutions in the epidural space and their site of action: a statistical study. Br. J. Anaesth. 34: 161 (1962).

\section{RÉSUMÉ}

Pour une anesthésie péridurale a l'occasion d'une césarienne en chirurgie réglée, on a injecté dans l'espace péridural de la parturiente $20 \mathrm{ml}$ de chlorprocaine trois pour cent. Dix minutes après l'injection de l'anesthésique, on a observé au côté gauche un syndrôme de Horner. Le niveau anesthésique atteignait la septième cervicale de ce côté. Trente minutes après l'injection de la dose initiale de chlorprocaine, une dose supplémentaire de chloroprocaine trois pour cent $10 \mathrm{ml}$ fut réinjectée. Le syndrome de Horner réapparut en huit minutes pour persister pendant vingt minutes. 
L'apparition d'un syndrome de Horner chez la parturiente sous analgésie épidurale pendant le travail n'est pas exceptionnelle mais n'a pas été rapportée jusqu'ici chez la parturiente dont le travail n'est pas commencé et le mécanisme en cause parait douteux. Dans le cas présent on pourrait l'expliquer par l'hypothèsee suivante: une petite dose d'anesthésique local fut nécessaire pour provoquer l'apparition du syndrôme initial et la dose subséquente injectée. bien que réduite en volume a suivi la voie ouverte par la dose initiale pour reproduire le syndrôme. 